\title{
EXPERIMENTAL STUDIES ON CHOLERA IMMUNIS- ATION: THE PROTECTIVE IMMUNOGENICITY IN RABBITS OF MONOMERIC AND POLYMERIC CRUDE EXOTOXIN
}

\author{
J. HOLMGREN \\ Institute of Medical Microbiology, University of Göteborg, Göteborg, Sweden
}

THE extensive diarrhoea in Asiatic cholera is due to the action on the gut of a protein exotoxin produced by the cholera vibrios (Pierce, Greenough and Carpenter, 1971). In experimental animals, protective immunity has been demonstrated after immunisation with crude or purified toxin or toxoids (Curlin and Carpenter, 1970; Curlin et al., 1970; Finkelstein, 1970; Burrows, Kaur and Cercavski, 1971; Fujita and Finkelstein, 1972; Holmgren et al., 1972). However, optimal conditions for inducing protection remain to be analysed with respect to the nature of the immunogen and the mode of immunisation. The purpose of this series of papers is to elucidate in experimental animals aspects of potential significance for immunisation against cholera in humans. In the present report are studied changes in immunogenicity of crude toxin during storage and their relation to aggregation of the toxin molecules. The host response to immunisation is also studied with the purpose of elucidating the magnitude, duration, and "memory function" of protective antitoxic immunity and its relation to serum-antibody levels.

\section{MATERIAL AND METHODS}

Toxin. Crude toxin for immunisation consisted of culture filtrate from Vibrio cholerae strain no. 569B (lot no. 4493G from National Institutes Health, Bethesda, Md, USA) which was purified about ten-fold before use (Holmgren, Lönnroth and Ouchterlony, 1971). The purification consisted of ultrafiltration of the dissolved freeze-dried filtrate through a "Diaflo" pellicon membrane (Amicon Corp., Lexington, Mass., USA) retaining molecules bigger than about 25,000 in molecular weight. The retentate was lyophilised and then contained 0.1-0.3 per cent. pure toxin $(\mathrm{w} / \mathrm{w})$ as estimated by neutralisation-inhibition experiments (Holmgren et al., 1971). Its toxicity or permeability factor (PF) activity in the intradermal skin test (Craig, 1965) was estimated as 10,000 blueing doses (BD) per mg.

The preparation was stored at $4^{\circ} \mathrm{C}$ for 2 wk in a glass bottle with screw cap which was kept in a desiccator with silica-gel drying powder, when a portion was taken and dissolved in phosphate-buffered saline $(0 \cdot 15 \mathrm{M}, \mathrm{pH} 7 \cdot 2)$ for use as an immunising agent and in gelfiltration experiments. This material will be referred to as "fresh toxin". After another $6 \mathrm{wk}$ at $4^{\circ} \mathrm{C}$, when the bottle had been opened several times without precautions to avoid condensation, another portion-" aged toxin "-was dissolved for similar use. Fractions of the aged toxin were also prepared as described in the Results.

Toxin for the challenge experiments consisted of the lyophilised culture filtrate used for preparation of the immunising agents. It was dissolved in phosphate-buffered saline less than $1 \mathrm{hr}$ before the challenge experiments. The least amount dissolved each time was 100 $\mathrm{mg}$ to minimise errors due to uneven distribution of active toxin.

Received 9 Oct. 1972; accepted 17 Jan. 1973.

J. MED. MICROBIOL.-VOL. 6 (1973) 
Immunisation. Six- to 8 -wk-old rabbits were immunised by subcutaneous injections, when not otherwise stated, of $12.5 \mathrm{mg}$ of toxin preparation. One or two injections were given; the interval between primary and secondary doses was $3 \mathrm{wk}$. Serum samples were taken immediately before immunisation and on the day of challenge.

Ileal-loop challenge. The technique described by Burrows and Musteikis (1966) was employed with the minor modifications previously reported (Holmgren et al., 1972). The amount of toxin required to give a 50 per cent. reaction (ED50) was determined according to Burrows and Musteikis. Each value was based on the results from five to eight animals, except one value based on not less than 12 animals. The reproducibility of such determinations is reported to be within about 5 per cent. (Kasai and Burrows, 1966).

Serological methods. Antibodies in serum capable of neutralising the PF activity of toxin were titrated as described by Benenson et al. (1968).

Gel filtration. Gel filtration of portions of the toxin preparations used for immunisation was performed through a Sephadex G-200 column. The eluting buffer was an ammonium acetate buffer $(0.5 \mathrm{M}, p \mathrm{H} \mathrm{7.2})$; the dimensions of the column were $70 \times 2.5 \mathrm{~cm}$ and the flowrate $16 \mathrm{ml}$ per hr. After spectrophotometry at $280 \mathrm{~nm}$ the eluate was pooled in equally sized fractions, numbered 1 to 8 in order of elution. A specimen of human serum was filtered immediately before each of the test runs for reference purposes.

\section{RESULTS}

\section{Immunogenicity of "fresh" and "aged" toxin}

Serum antibody. Table I shows that the aged toxin was a considerably more potent immunogen than the fresh material. Thus a single injection of aged toxin induced measurable levels of serum antibody within 3-5 days in contrast to the fresh toxin which only irregularly caused formation of antibodies in low amounts after 3 wk. Also in the animals given two injections, aged toxin was the superior immunogen. With both preparations higher serum-antibody titres were noted after two injections than after one injection, indicating induction of memory by the first injection. In no case did the preimmunisation sera contain demonstrable neutralising activity.

Gut immunity. The protective immunity in the gut to toxin challenge was compared between the animal groups immunised with fresh or aged toxin and control animals which were not immunised. This was done in the ileal-loop system. The loop response to challenge with various doses of toxin was tested in 12 control animals with challenge doses of toxin varying from $0.1 \mathrm{mg}$ to $1.6 \mathrm{mg}$. There was always a marked difference between loops recorded as positive $(>1.0 \mathrm{ml}$ of fluid per $\mathrm{cm}$ of ileum) and those recorded as negative because the negative loops generally contained no measurable fluid, only rarely had more than $0.2 \mathrm{ml}$ per $\mathrm{cm}$, and in no instance more than $0.5 \mathrm{ml}$ per $\mathrm{cm}$. Table II shows that doses of $0.4 \mathrm{mg}$ and above were toxic in 90-100 per cent. of the loops. The ED50 was estimated to be $0.32 \mathrm{mg}$ as shown in fig. 1 . Three subsequent ED50 determinations spaced over a period of $3 \mathrm{mth}$ with the same batch of toxin gave values of $0 \cdot 30,0.31$, and $0.32 \mathrm{mg}$ respectively for groups of five non-immunised animals. These data, which are within 10 per cent. agreement, verify the high accuracy and reproducibility of ED50 determinations reported by Kasai and Burrows.

The immunised animals were challenged with toxin doses based on the results from the control animals, from $0.4 \mathrm{mg}$ and above. Curves similar to 
those for the control animals (fig. 1) were obtained for the immunised animals and the ED50 values were determined. Table II shows that with fresh as well as aged toxin an increased resistance to toxin could be induced by immunisation. With both immunogens two injections gave a much better protection

TABLE I

Serum-antitoxin titres after immunisation with fresh and with aged toxin

\begin{tabular}{|c|c|c|c|c|}
\hline \multirow{3}{*}{$\begin{array}{l}\text { Immunising } \\
\text { agent }\end{array}$} & \multicolumn{4}{|c|}{$\begin{array}{c}\text { Mean (and range of) antibody titres- }-\log _{3} \text { in rabbits } \\
\text { given }\end{array}$} \\
\hline & \multicolumn{2}{|c|}{ one injection and tested } & \multicolumn{2}{|c|}{ two injections* and tested } \\
\hline & $\begin{array}{l}3-5 \text { days } \\
\text { later }\end{array}$ & $\begin{array}{l}3 \text { wk } \\
\text { later }\end{array}$ & $\begin{array}{l}4 \text { days } \\
\text { later }\end{array}$ & $\begin{array}{l}2 w k \\
\text { later }\end{array}$ \\
\hline Fresh toxin & $<1$ & $1 \cdot 2(0-2)$ & $4 \cdot 8(4-6)$ & $6 \cdot 2(4-7)$ \\
\hline Aged toxin & $3 \cdot 2(3-4)$ & & $7 \cdot 6(6-11)$ & \\
\hline
\end{tabular}

* Identical doses $3 \mathrm{wk}$ apart; serum tested the stated number of days after the second injection.

than one. The aged toxin was superior to the fresh toxin with respect to protective immunogenicity; in fact a single injection of aged material gave a better immunity than two injections of fresh toxin. The protective immunity seemed to be of short duration; 2 wk after immunisation the ED50 was lower than it had been 4 days after immunisation.

TABLE II

Gut immunity to toxin challenge after various immunisation procedures

\begin{tabular}{|c|c|c|c|c|c|c|c|c|c|c|c|c|c|}
\hline \multirow{2}{*}{$\underset{\text { agent }}{\text { Immunising }}$} & \multirow{2}{*}{$\begin{array}{l}\text { Number } \\
\text { of } \\
\text { injections }\end{array}$} & \multirow{2}{*}{$\begin{array}{l}\text { Time to } \\
\text { challenge }\end{array}$} & \multicolumn{9}{|c|}{$\begin{array}{l}\text { Percentage of loops positive* to toxin } \\
\text { challenge of }(\mathrm{mg})\end{array}$} & \multirow{2}{*}{$\mathrm{ED} 50(\mathrm{mg})$} & \multirow{2}{*}{$\begin{array}{l}\text { Protection } \\
\text { factor } \dagger\end{array}$} \\
\hline & & & 0.1 & 0.2 & 0.3 & 0.4 & 0.6 & 0.8 & 1.6 & $3 \cdot 2$ & 6.4 & & \\
\hline None & 0 & 0 & 9 & 8 & 50 & 91 & 100 & 100 & 100 & $\ldots$ & $\ldots$ & 0.32 & 1.00 \\
\hline $\begin{array}{l}\text { Fresh toxin } \\
\text { Fresh toxin } \\
\text { Fresh toxin }\end{array}$ & $\begin{array}{l}1 \\
2 \\
2\end{array}$ & $\begin{array}{c}3-5 \text { days } \\
4 \text { days } \\
2 \text { wk }\end{array}$ & $\begin{array}{l}\ldots \\
\ldots \\
\ldots\end{array}$ & $\begin{array}{l}\ldots \\
\ldots \\
\cdots\end{array}$ & $\begin{array}{l}\ldots \\
\ldots \\
\ldots\end{array}$ & $\begin{array}{r}75 \\
0 \\
40\end{array}$ & $\begin{array}{l}\ldots 0 \\
40\end{array}$ & $\begin{array}{r}100 \\
60 \\
100\end{array}$ & $\begin{array}{r}100 \\
60 \\
100\end{array}$ & $\begin{array}{l}\ldots \\
\cdots \\
\cdots\end{array}$ & $\begin{array}{l}\ldots \\
\ldots \\
\ldots\end{array}$ & $\begin{array}{l}0.45 \\
1.50 \\
0.58\end{array}$ & $\begin{array}{l}1.41 \\
4.69 \\
1.82\end{array}$ \\
\hline $\begin{array}{l}\text { Aged toxin } \\
\text { Aged toxin }\end{array}$ & $\frac{1}{2}$ & $\begin{array}{l}4-5 \text { days } \\
4 \text { days }\end{array}$ & $\ldots$ & $\begin{array}{l}\cdots \\
\ldots\end{array}$ & $\begin{array}{l}\cdots \\
\cdots\end{array}$ & $\begin{array}{l}0 \\
0\end{array}$ & $\cdots$ & $\begin{array}{r}20 \\
0\end{array}$ & $\begin{array}{l}60 \\
11\end{array}$ & $\begin{array}{l}80 \\
60\end{array}$ & $\dddot{100}$ & $\begin{array}{l}2 \cdot 80 \\
3 \cdot 90\end{array}$ & $\begin{array}{r}8 \cdot 75 \\
12 \cdot 20\end{array}$ \\
\hline
\end{tabular}

* Holmgren et al. (1972).

$\uparrow$ ED50 of immunised group divided by ED50 of control group concurrently tested.

There was little correspondence between the degree of gut resistance and the serum levels of neutralising antibodies (Tables I and II). Thus some functional immunity was observed 3-5 days after a single injection when no or only low serum-antitoxin titres were recorded. Furthermore one injection of the aged toxin gave better protection than two injections of the fresh toxin despite lower serum titres. Finally, the latter immunisation procedure resulted in a marked 
decrease of the gut immunity from day 4 to day 14 during which period the serum titres rose.

\section{Molecular size of fresh and aged toxin}

At the time of immunisation portions of the fresh and the aged toxins were dissolved in water. The aged but not the fresh toxin contained a fraction

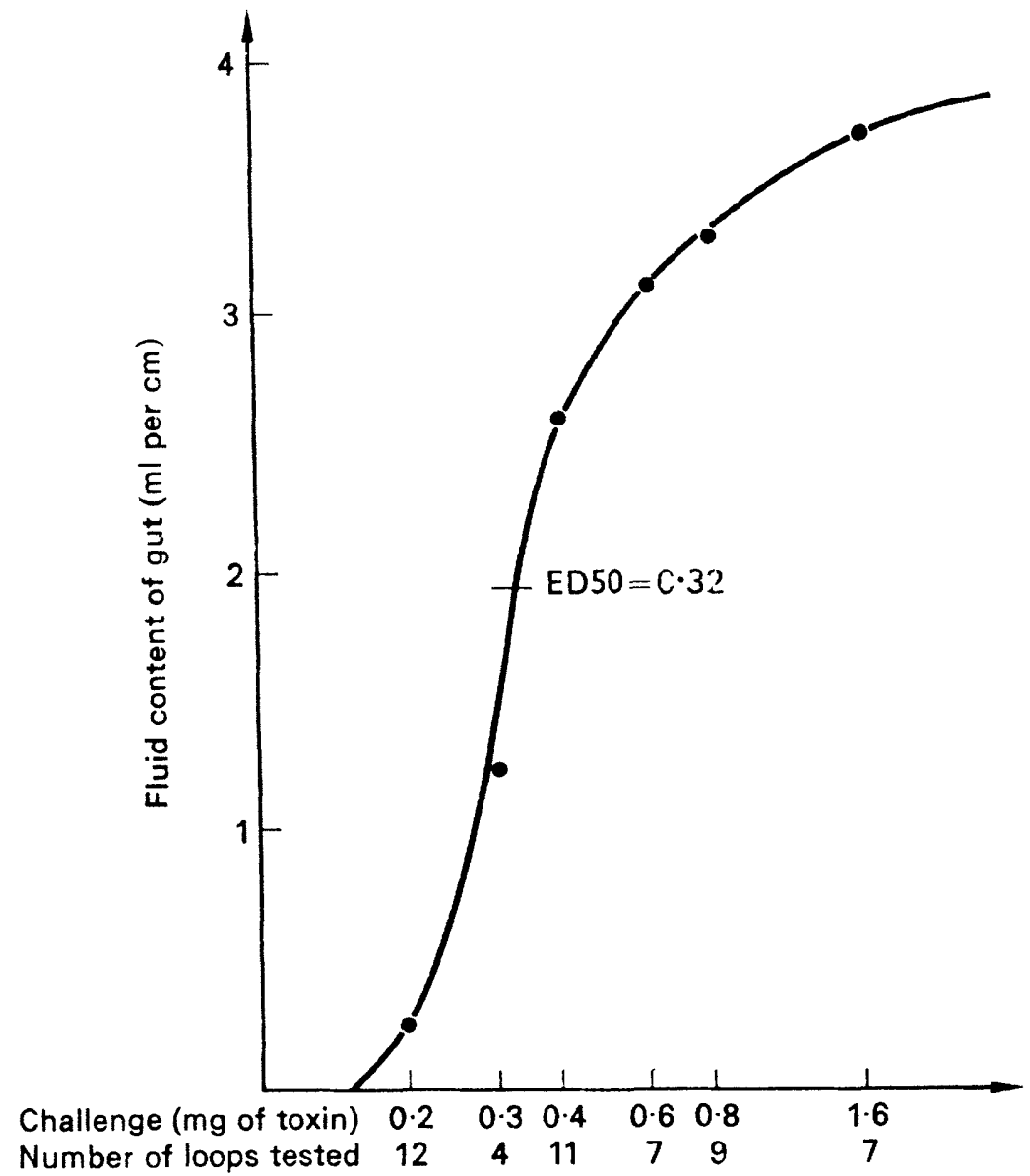

FIG. 1.-Determination of ED50 in the control group. Arithmetic-mean values of fluid content in challenged loops are plotted against toxin doses (see Burrows and Musteikis, 1966).

that sedimented on centrifugation at $14,000 \mathrm{~g}$ for $30 \mathrm{~min}$. This sediment fraction when resuspended and tested in the intradermal test was highly toxic, i.e., it contained polymeric toxin. The supernatant of the centrifuged aged toxin had less than 10 per cent. of the toxic activity of the fresh toxin and a different distribution of the activity with regard to molecular size. Thus on gel filtration through Sephadex G-200 all the toxic activity of the fresh toxin showed a filtration rate slightly slower than that of human serumalbumin, while the aged toxin contained in addition much PF-active material 
with a faster filtration rate (fig. 2). These results indicate that on storage the monomeric fresh toxin had to a considerable extent become converted to the oligomeric or polymeric state.

Immunogenicity of monomeric, oligomeric, and polymeric toxin

The immunogenicity of monomeric (Sephadex fraction 6), oligomeric (fraction 2), and polymeric (insoluble) toxin fractions of the aged preparation

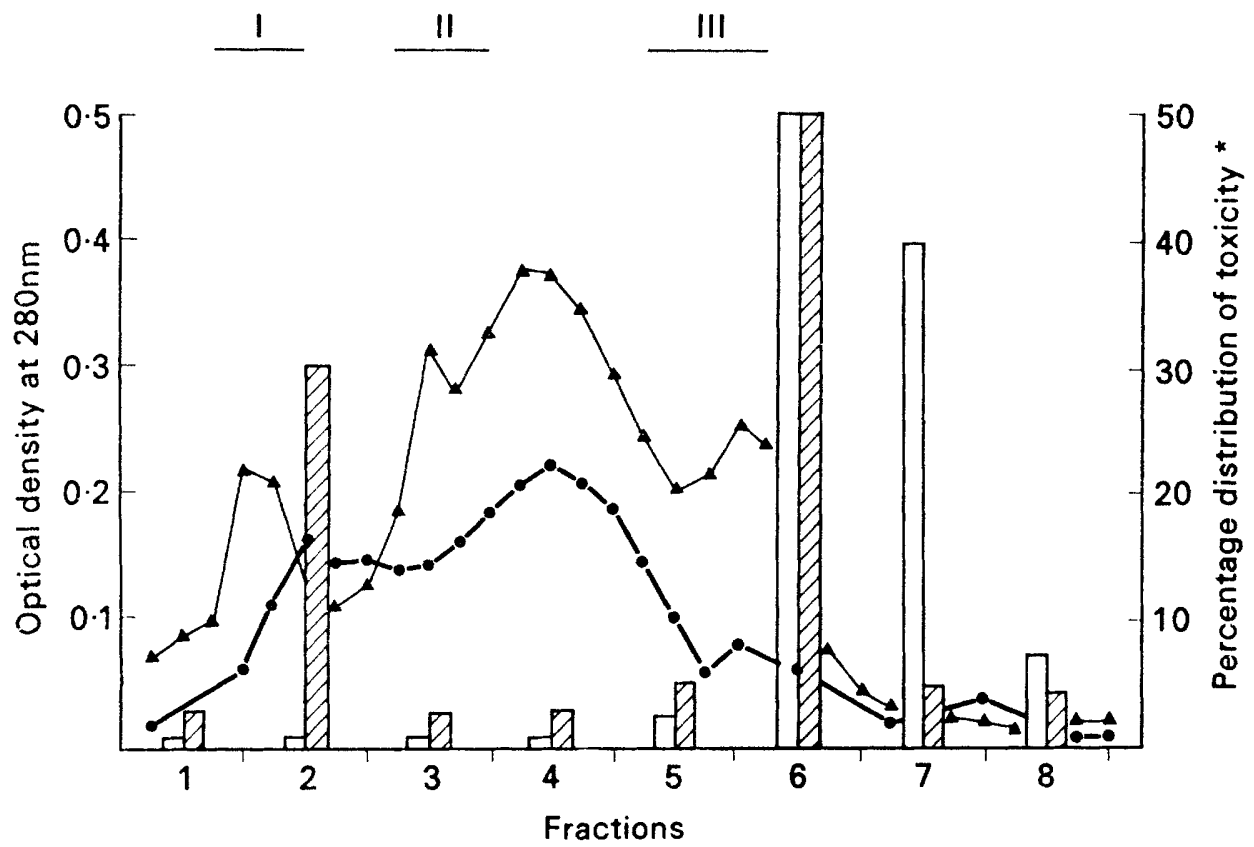

FIG. 2.-Gel-filtration pattern ( $\mathbf{A}-\boldsymbol{\Lambda}$ ) and distribution of skin-test toxicity (open bars) of fresh toxin and aged toxin (- and hatched bars). Shown for reference purposes are the filtration rates of the three main protein fractions (I-III) of human serum after separation through the column.

* See Burrows and Musteikis (1966).

was compared. These fractions were adjusted to equal toxin content on the basis of their antibody-binding capacity in neutralisation-inhibition experiments before immunisation. After a single injection, equivalent to about 20 mg of crude toxin, and challenge 6-7 days later, resistance was two- to threefold that of non-immunised controls, the highest resistance being induced by the polymeric toxin (table III). A better immunogenicity of the polymer, as expressed by the ED50 values, than of the oligomer and monomer was also suggested after two injections (table IV). Unfortunately the limited amounts of these toxin fractions made all the immunisation doses much less than optimal. This probably explains why the ED50 values were lower after two injections than after one and why serum-antibody formation was not seen, 
because lower antigen doses were administered in the two-injection experiment (cf. tables III and IV).

TABLE III

Protective antitoxic immunity after a single subcutaneous injection of toxin in different aggregation states

\begin{tabular}{lcc}
\hline \multicolumn{1}{c}{$\begin{array}{c}\text { Immunising } \\
\text { agent* }\end{array}$} & ED50 (mg) & $\begin{array}{c}\text { Protection } \\
\text { factor }\end{array}$ \\
\hline None & 0.33 & $\ldots$ \\
Monomeric toxin & 0.78 & $2 \cdot 37$ \\
Oligomeric toxin & 0.72 & $2 \cdot 18$ \\
Polymeric toxin & 0.96 & 2.92 \\
\hline \multicolumn{1}{c}{$*$ See text. } & + See table II.
\end{tabular}

DisCUSSION

These results verify earlier reports (Curlin and Carpenter, 1970; Curlin et al., 1970; Finkelstein, 1970; Burrows et al., 1971; Fujita and Finkelstein, 1972; Holmgren et al., 1972) of protective antitoxic immunity in experimental animals after parenteral immunisation with cholera exotoxin. They suggest that the addition of toxoid to conventional whole-cell cholera vaccine might

TABLE IV

Protective antitoxic immunity after two subcutaneous injections of toxin in different aggregation states

\begin{tabular}{|c|c|c|}
\hline $\begin{array}{l}\text { Immunising agent } \\
\text { and dose* }\end{array}$ & ED50 (mg) & $\begin{array}{l}\text { Protection } \\
\text { factor } \dagger\end{array}$ \\
\hline $\begin{array}{l}\text { None } \\
\text { Monomeric toxin } \frac{1}{5} \\
\text { Oligomeric toxin } \frac{\frac{1}{30}}{\frac{1}{5}} \\
\text { Polymeric toxin } \frac{1}{30} \\
\frac{1}{5}\end{array}$ & $\begin{array}{l}0.30 \\
0.53 \\
0.44 \\
0.66 \\
0.44 \\
0.83\end{array}$ & $\begin{array}{l}1.74 \\
1.47 \\
2.20 \\
1.47 \\
2.77\end{array}$ \\
\hline
\end{tabular}

* See text; the doses were $\frac{1}{5}$ and $\frac{1}{50}$ of those indicated in table III. † See table II.

result in a more potent immunogen than is now available. This is the more likely as it seems that the observed values of gut resistance to a bolus of exotoxin would represent a much more pronounced immunity to the choleragenic effect of toxin-producing vibrios (Finkelstein; Fujita and Finkelstein). The present study indicates that the toxin or toxoid should be administered at least twice, because a " memory" with regard to protective antitoxic immunity and to serum-antitoxin formation was demonstrated.

The study showed clearly that aged toxin was superior to the fresh toxin with regard to induction of serum antibodies and to protective immunity in 
the gut. Gel-filtration analyses indicated that while in the fresh preparation the exotoxin was almost exclusively monomeric it was largely polymeric or oligomeric in the aged preparation. These observations suggest that the aggregation state of the toxin affects its immunogenicity. This hypothesis was supported by the comparison of protective immunogenicity of separated polymeric, oligomeric, and monomeric exotoxin from the aged preparation. Polymeric toxin was more immunogenic than the two other fractions, which did not seem to differ in protective immunogenicity. These observations are similar to those made on other protein antigens for which only aggregatecontaining material was immunogenic and removal of the aggregates resulted in immunological tolerance (Weigle, Chiller and Habricht, 1971). They also fit well with the recent observation of Fujita and Finkelstein that procholeragenoid, which is a polymeric cholera exotoxoid, was superior to the other tested toxoids of lower molecular weight with respect to protective immunogenicity in mice.

The relative importance of serum antitoxins and locally formed gut immunity is not established. Three observations in the present study are relevant to this problem. The rise in antitoxic gut immunity after immunisation was more rapid than the rise in serum-antitoxin levels. A single injection with aged toxin gave a better protective immunity than did two injections with fresh material, although the latter procedure resulted in higher serum-antitoxin titres. Thirdly, in spite of increased serum-antibody levels from day 4 to day 14 after a second injection of antigen the protective immunity in the gut decreased during the same period. These observations point to a divergence between the systemic-immune system and a local gut-immune system, the latter system probably being responsible for a major part of the protective antitoxic immunity in the experimental situations quoted. This hypothetical model is similar to that postulated by Burrows, Elliot and Havens (1947) in their early work on the antibacterial component of the immunity. It is supported by the observation of Holmgren et al. (1972) that protective antitoxic immunity is developed by intestinally immunised rabbits in the absence of serum antitoxins. Consequently, the data presented may suggest a " memory function" for local immunity, which has previously been difficult to demonstrate (Newcomb, Ishizaka and DeVald, 1969; Ogra, 1969). However, it is known from work on dogs (Curlin et al., 1970) and rabbits (Holmgren et al., 1972) that passive administration of antiserum into the circulation also confers protective antitoxic immunity. Therefore, the relative importance for protection of serum as compared with local gut-antitoxins cannot yet be definitely evaluated. Both may be effective, the relative significance of each depending on immunisation route, time after immunisation, etc.

\section{SUMMARY}

Subcutaneous immunisation of rabbits with crude cholera exotoxin induced a functional immunity in the gut to toxin challenge that was superior to that of non-immunised controls. Two injections given 3 wk apart gave markedly better protection than one injection. The functional immunity appeared to 
be of short duration, because the resistance 2 wk after a second injection was less than it was 4-5 days after immunisation. With prolonged storage of the crude toxin its immunogenicity increased markedly; this was related to aggregation of a considerable portion of the toxin. The correlation between the magnitude of immunity in the gut and the serum levels of neutralising antibodies was often poor suggesting that antibodies formed locally in the gut may be of significance for protection.

The skilled assistance of $\mathrm{Mr} \AA$. Andersson and Mrs G. Wallerström with the animal experiments is gratefully acknowledged. The gel-filtration separations were kindly performed by Dr I. Lönnroth.

This study was supported by a grant from the Swedish Medical Research Council (project no. B72-16X-3382). The author is the recipient of a personal research grant (B72-40P-3591-01) from this Council.

\section{REFERENCES}

Benenson, A. S., SaAd, A., Mosley, W. H., And Ahmed, A. 1968. Serological studies in cholera. 3. Serum toxin neutralization-rise in titre in response to infection with Vibrio cholerae, and the level in the "normal " populations of East Pakistan. Bull. Wld Hlth Org., 38, 287.

Burrows, W. J., Elliot, M. E., and Havens, I. 1947. Studies on immunity to Asiatic cholera. IV. The excretion of coproantibody in experimental enteric cholera in the guinea pig. J. Infect. Dis., 81, 261.

BURROWS, W., KAUR, J., AND CerCavsKI, LORA 1971. Discussion: the cholera enterotoxin and local immunity. Ann. N.Y. Acad. Sci., 176, 323.

BURRows, W. J., AND MusterkIs, G. M. 1966. Cholera infection and toxin in the rabbit ileal loop. J. Infect. Dis., 116, 183.

CRAIG, C. P. 1965. A permeability factor (toxin) found in cholera stools and culture filtrates and its neutralization by convalescent cholera sera. Nature, Lond., 207, 614.

CURLIN, G. T., AND CARPENTER, C. C. J. 1970. Antitoxic immunity to cholera in isolated perfused canine ileal segments. J. Infect. Dis., 121, S132.

Curlin, G. T., Craig, J. P., Subong, A., and Carpenter, C. C. J. 1970. Antitoxic immunity in experimental canine cholera. J. Infect. Dis., 121, 463.

Finkelstein, R. A. 1970. Antitoxic immunity in experimental cholera: observations with purified antigens and the ligated ileal loop model. Infect. Immun., 1, 464.

FUITTA, K., AND FINKELSTEIN, R. A. 1972. Antitoxic immunity in experimental cholera: comparison of immunity induced perorally and parenterally in mice. J. Infect. Dis., $125,647$.

HolmGren, J., ANDERsson, Å., Wallerström, G., and OUCHTERLony, Ö. 1972. Experimental studies on cholera immunization. 2. Evidence for protective antitoxic immunity mediated by serum antibodies as well as local antibodies. Infect. Immun., 5, 662.

HOLMGREN, J., LÖNNROTH, I., AND OUCHTERLONY, Ö. 1971. Immunochemical studies of two cholera toxin-containing standard culture filtrate preparations of Vibrio cholerae. Infect. Immun., 3, 747.

KASAI, G. J., AND BURRows, W. 1966. The titration of cholera toxin and antitoxin in the rabbit ileal loop. J. Infect. Dis., 116, 606.

Newcomb, R. W., IshizaKa, K., ANd DeVaid, B. L. 1969. Human IgG and IgA diphtheria antitoxins in serum nasal fluids and saliva. J. Immunol., 103, 215.

OGRA, P. L. 1969. The secretory immunoglobulin system of the gastrointestinal tract. In The secretory immunologic system, Washington, D.C., p. 259.

Pierce, N. F., Greenough, W. B., III, AND CARPENTER, C. C. J. 1971. Vibrio cholerae enterotoxin and its mode of action. Bact. Rev., 35, 1 .

Weigle, W. O., Chiller, J. M., aNd Habricht, Gail S. 1971. Immunological unresponsiveness: cellular kinetics and interactions. In Progress in immunology, edited by $\mathbf{B}$. Amos, New York and London, p. 311. 